\title{
Dyeing and Fading of Human Hair Translucent Keratin Film by Semi-Permanent Hair Colors*
}

\author{
Toshihiro Fujii, Misaki Imai, Kaori Hayashi, Yumiko Ito \\ ${ }^{* *}$ Faculty of Textile Science and Technology, Shinshu University
}

\begin{abstract}
The dyeing and fading of semi-permanent hair colors were examined using transparent human hair keratin film. Among four kinds of commercial semi-permanent hair colors, the translucent keratin film was significantly dyed with three products. The coloring was dependent on dyeing time and increasing dyeing number, and the latter was important to gain deeper dyeing. When the film was dyed by two different products and analyzed by a spectrophotometer, spectra of the average absorbance were independent of the dyeing order. Compared with the dyeing of oxidative hair color products, no significant formation of cysteic acid was found in the films dyed with semi-permanent hair colors. When the dyed films were immersed in distilled water and tap water, the fading by tap water was faster than that by distilled water. The addition of EDTA to the tap water suppressed the color fading, whereas the addition of $\mathrm{CaCl}_{2}$ to distilled water caused the fading, indicating that metal ions will be closely related to the fading by water. The fading was also observed when the dyed films were exposed to artificial light $(300-2500 \mathrm{~nm})$ using a solar simulator. The fading was conveniently measured and the rate of change indicated the difference between the products. These results suggest that translucent keratin film will be useful to develop damage-free, anti-washout, and less-photofading hair color products.
\end{abstract}

Key words : keratin film, semi-permanent hair color, single dyeing, double dyeing, spectrophotometric analysis, cysteic acid, water fading, light fading, metal ion, substitute

* Received, December 16, 2016; Accepted, February 24, 2017

** 3-15-1, Tokida, Ueda 386-8567, Japan

doi.org/10.5107/sccj.51.237

(C) 2017 The Society of Cosmetic Chemists of Japan 


\title{
半永久染毛料によるヒト毛髪由来の 透明型ケラチンフィルムの染色と退色*
}

\author{
藤 井敏 弘, 今井美沙季, 林香, 伊藤 弓子
}

**信州大学 繊維学部

\begin{abstract}
半永久染毛料による染色と退色に関して, 透明型ケラチンフィルムを使用して調べた。市販されて いる 4 種の製品を使用したところ, 3 製品においてケラチンフィルムの明確な着色がみられた。着色 と退色は分光光度計によるスペクトル（300 800 nm) 分析と分光測色計による色差变化により測定 ができた。着色は染色回数と染色時間に依存しており, 濃い着色を得るには染色時間よりも, 染色の 回数を増やすことが重要であった。異なる 2 種類の染毛料で連続して染色したケラチンフィルムは, 個々の染色で得られたスペクトルを加算した平均的なスペクトルが得られた。過酸化水素を含有して いる酸化染毛剂の処理により形成されるダメージ分子のシステイン酸は, 染色回数を重ねても半永久 染毛料においては検出されなかった。染色ケラチンフィルムからの水洗による色落ちを調べたとこ 了, 色差值の低下は蒸留水よりも水道水の方が約 2 倍も高く, 金属イオンが原因物質であった。ソー ラーシミュレータを用いた光照射により経時的な退色を観察することができた。これらの退色におい ては染色に使用した製品間での相違がみられた。ケラチンフィルムは半永久染毛料による染色と退色 を簡便に検出し，評価するのに有用であることが明らかとなった。
\end{abstract}

\section{1. 緒言}

若さと美しさへの意識の高まりから，ヘアカラーの施術 率が, 特に50歳代以上の年代に扔いて高くなっている。 人口の減少と高齢化社会に入ったわが国において染毛料は 安定した化粧品目の 1 つであり続けることが推測できる。 実際，化粧品全体の出荷統計は 2017 年と 2014 年を比較し てほとんど伸びていないのに対して，2014 年の染毛料の 出荷額は 2007 年と比べて $5.3 \%$ も増加している1)。最も繁 用されている永久 (酸化) 染毛剂と比較して, 半永久染毛 料はアレルギー反応を惹起させる物質や過酸化水素などの 酸化剂を含まない。そのため, 肌や髪の毛を痛めにくく, アレルギーも引き起こしにくい施術と考えられている。し かしながら, 半永久染毛料による染髪は退色を起こしやす く, 発色とその保持に優れたへアカラー製品の開発は今後 も継続すべき課題と考えられる。

毛髪のコルテックス部位は永久染毛剂ばかりか半永久染 毛料のターゲットとして考元れている。コルテックスの タンパク質から作られているケラチンフィルムは代替毛髪 として染毛料で使われる原料から製品までの評価に活用で

\footnotetext{
*2016.12.16 受付, 2017.2.24 採用

** $\overline{1} 386-8567$ 上田市常田 3-15-1
}

きることが想定され，実際に永久染毛剂により染色を受け ることを明らかにしてきている2)。今までのケラチンフィ ルム（従来型）はほぼ白色で光透過性を示さない不透明型 フィルムで，SEMに扔いて $0.5 \mu \mathrm{m}$ 以下の微粒子が凝集し た微細な網目構造が観察されている2),3)。ケラチンフィル ムの作製条件を変えると光透過性を示寸茶色を带びた透明 型フィルムが形成される ${ }^{4)}$ 。透明型フィルムでは不透明型 フィルムがもつようなネットワーク構造はみられず，同量 のタンパク質量においてフィルム厚は約半分となり,より パッキングされた状態で自己集合して構築されている。興 味深いことに，いくつかの酸化染毛剂により透明型ケラチ ンフィルムは不透明型フィルム以上の染色を受ける。ま た，透過光を使用した測定に適していることから，汎用機 器として使われている分光光度計を使用しての分析が容易 である5)。

半永久染毛料による頭髪への染色は, 酸化物質を使用す る永久染毛剂と比べてダメージレスな施術として知られて いる(6), 7)。染料や色素の染色部位はキューティクルとその やや内側とされている。一方，コルテックスを構成してい るケラチンとケラチン結合タンパク質（KAPs）の一部は キューティクルにも分布していることが知られている8)。 このことから，半永久染毛料や一時染毛料に分類されてい る非酸化染毛剂や天然系の染毛剂がケラチンと KAPs から 
形成されているケラチンフィルムと結合・吸着し，着色で きることが考えられた。そこで，市販されている半永久染 毛料を使用して透明型ケラチンフィルムへの染色処理を 行ったところ, 酸化染毛剂の場合と同様に染色がみられ た。

本研究に扔いては, 半永久染毛料と透明型ケラチンフィ ルムを組合せて, (1) 染色とその分析, (2) 染毛料の組合せ と着色, (3) システイン酸の分析, (4) 水と光による退色評 価への適用を中心とした結果を報告する。

\section{2. 実験}

\section{1. 透明型および不透明型ケラチンフィルムの作製と 分析}

化学的な施術をしていない複数のボランティアから提供 された頭髪は， $5 \sim 20 \mathrm{~mm}$ に裁断後，信大法溶液 $(5 \mathrm{~mol} / \mathrm{L}$ 尿素, $2.6 \mathrm{~mol} / \mathrm{L}$ チ才尿素, $250 \mathrm{mmol} / \mathrm{L}$ DTT, $25 \mathrm{mmol} / \mathrm{L}$ Tris-HCl, pH 9）に浸し, $50^{\circ} \mathrm{C}$ 下で約 24 時間抽出を行った。 ろ過と遠心操作を行い，毛髪タンパク質溶液（20３0 mg

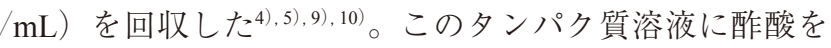
混合し，蒸留水を満たした培養シャーレ（直径 $35 \mathrm{~mm}$ ）に 素早くキャスティングをしてフィルムを形成させた。透明 型のフィルム形成には高濃度酢酸（50〜100 $\mathrm{mmol} / \mathrm{L} ）$ ，不 透明型のフィルム形成には低濃度酢酸（20 30 mmol/L） を用いた。フィルムはフィルター水で 24 時間以上洗浄し た後に，自然乾燥した。タンパク質溶液からフィルムへの 変換を示す回収率は，質量測定により調べた。タンパク質 量は, Bradford 法と質量法で測定した11)。

\section{2. 半永久染毛料による染色とその評価}

市販されているトリートメントタイプで非酸化系の染毛 料を 4 種類購入して使用した（製品 $\mathrm{A} \sim \mathrm{D}$ )。直径 $35 \mathrm{~mm}$ 培養プラスチックシャーレの底面のケラチンフィルムと ベージュ色の毛髪束 (ビューラックス社から購入; 約 $0.5 \mathrm{~g}$ ) に約 $1.5 \mathrm{~g}$ の染毛料を添加し，筆で均一になるように迅速 な塗布をし, $37^{\circ} \mathrm{C}$ の保温庫に入れて 20 分間保温した。染 色後のフィルムと毛髪はシャワー水約 $10 \mathrm{~L}$ での洗浄によ り染毛料を十分に落とし，室温下で一晚以上乾燥させて測 定などに使用した。複数回数の染色では $37^{\circ} \mathrm{C}$ 下で 20 分間 の反応を基準として, 室温で一晚以上乾燥させた後の試料 に対して次の染色を行った。これを 3 回まで繰り返した。

着色は分光測色計 (NF 333 ; 日本電色工業) を用いて測 定した。白板を基準として $\Delta E=\sqrt{\left(\Delta L^{*}\right)^{2}+\left(\Delta a^{*}\right)^{2}+\left(\Delta b^{*}\right)^{2}}$ で 色差を計算した ${ }^{2), 4), 12)} 。 \Delta E^{*}$ は $\Delta E($ (染色後 $)-\Delta E($ 染色前 $)$ とした。透明型ケラチンフィルムの吸光度は紫外可視分光 光度計（UV-2700；島津製作所）を用いて測定した。染色 したフィルムを試料側のホルダーに両面テープで貼り付
け，未染色のフィルムをブランクとして，300～ $800 \mathrm{~nm}$ ま での波長でスキャンした。1 試料/シャーレあたり，4 カ所 の異なる場所を測定しその平均值士S. D. を求めて使用し た。

\section{3. フーリエ変換型赤外分光 $(F T-I R) / A T R$ 測定}

未染色と染色後のケラチンフィルムはシャーレから掻き 取った後，乳鉢で粉体とした。一方，毛髪試料は細断した 後, マルチビーズショッカー $(\mathrm{MB} 755 \mathrm{U}(\mathrm{S})$; 安井器械) で粉体とした。赤外線吸収測定はフーリエ変換赤外分光光 度計（IR Prestige-21；島津製作所）の ATR 法を使用した。 スキャン回数は 50 回, 分解能は $4 \mathrm{~cm}^{-1}$, 波数範囲は 4000 $600 \mathrm{~cm}^{-1}$ の条件で測定し, $1076 \mathrm{~cm}^{-1}$ の吸収スペクトルで 規格化を行い解析した22),4),5), 13)。

\section{4. 退色実験と評価}

製品 B と C で 1 回染色した透明型ケラチンフィルム（乾 燥品）を $40^{\circ} \mathrm{C}$ に保温した蒸留水，水道水（長野県上田市 の水道水; 硬度 $45 \mathrm{mg} / \mathrm{L}), 0.5 \mathrm{mmol} / \mathrm{L} \mathrm{CaCl}$ 液で 60 分間 浸した。最初の浸水液を回収後，全ての試料は蒸留水で洗 浄した2),5)。自然乾燥させたフィルムと最初の浸水液の色 差と吸光度の測定から退色を数值化した。

光照射には，太陽光照射システム（セリック株式会社 SXL-500 V2；300～2500 nm）を使用した。紫外線強度（365 $\mathrm{nm})$ は $1.8 \mathrm{~mW} / \mathrm{cm}^{2}$ の条件として, 製品 $\mathrm{B}$ と C で 1 回染 色した透明型ケラチンフィルムの表面ができるだけ全面的 に照射されるように配置して, 各時間照射後に色差と吸光 度を測定した5)。

\section{3. 結果と考察}

\section{1. トリートメントタイプ半永久染毛料による染色と 観察}

市販されているトリートメントタイプの半永久染毛料 （製品 $\mathrm{A} \sim \mathrm{D} ）$ の頭髪への染色条件は製品間で異なるが, ここでは $37^{\circ} \mathrm{C} て ゙ 20$ 分間の染色を基準とした。毛髪におい ては 4 製品すべて染色されるが，透明型と不透明型ケラチ ンフィルムに扔いては3 製品で明確な染色がみられた （Fig. - 1）。製品 $\mathrm{A} \sim \mathrm{C}$ は 7 10 種類の染料と色素が含まれ るのに対して，製品 $\mathrm{D} に$ に扔いては 3 種類と少ないことが 原因の 1 つと考えられた。次に，不透明型フィルム（17.7 $\mathrm{mg} / \mathrm{dish})$ より少ないタンパク質量の透明型フィルム（13.9 $\mathrm{mg} / \mathrm{dish})$ に扔いてより濃く染色されていることが，肉視 で判別することができた。この現象は永久染毛剤での染色 結果と一致することから ${ }^{5)}$ ，透明型ケラチンフィルムはへ アカラー剤による染着性が高いことが示された。

\section{2. 色差とスペクトルでの分析}

分光測色計を用いて Fig. -1 の 2 種類のフィルムと毛髮 
$\mathrm{T}$

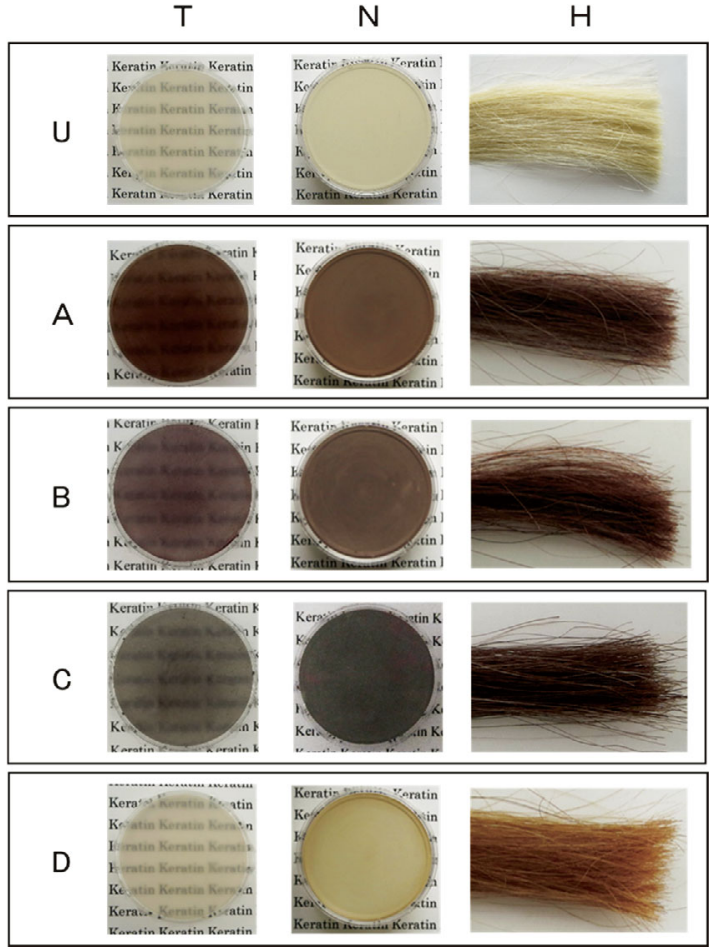

Fig.-1 External view of translucent $(\mathrm{T})$ and non-translucent $(\mathrm{N})$ keratin films and hair $(\mathrm{H})$ after treatment of semi-permanent hair colors.

The keratin films and hair were dyed with the commercial hair color reagents for $20 \mathrm{~min}$ at $37^{\circ} \mathrm{C}$. Symbols U, A, B, C, and D show Undyed state, Products A, B, C, and D, respectively.

の染色による色差の変化を測定した（Fig.-2（a））。不透明 型ケラチンフィルムと毛髪は製品 $\mathrm{D}$ を除いて類似した色 差值を示した。一方, 透明型ケラチンフィルムは不透明型 フィルムと比べ低いタンパク質量にもかかわらず $1.6 〜 2.0$ 倍も高い值を示した。両フィルムを可溶化してその成分を 電気泳動で分析したところ，ケラチンと KAPs で構成され

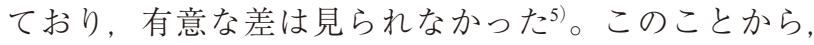
フィルムの構築が製品間の染色性に影響を与えていること が推測された。

次に, 透明型ケラチンフィルムの利点を活かし, 分光光 度計により 300～800 nm までの波長の吸光度を測定した

(Fig. -2(b))。製品 $\mathrm{A} \sim \mathrm{C}$ のいずれも $490 \mathrm{~nm}$ 付近に最大の 吸収ピークをもつ特徴があり，色合いの大きな差が認めら れない原因の 1 つと考えられた。この極大吸収に加えて,

製品 $\mathrm{A}$ では $583 \mathrm{~nm}$ に，製品 $\mathrm{B}$ では $576 \mathrm{~nm}$ と $616 \mathrm{~nm}$ に, 製品 $\mathrm{C}$ で $591 \mathrm{~nm}$ と $628 \mathrm{~nm}$ に小さなピークがみられた。 一方, 製品 D においては吸収とピークは認められなかった。

これらの結果, 各製品はピークの波長, 大きさ, 数から 特有のスペクトルパターンがあり, 染着性は透明型ケラチ (a)

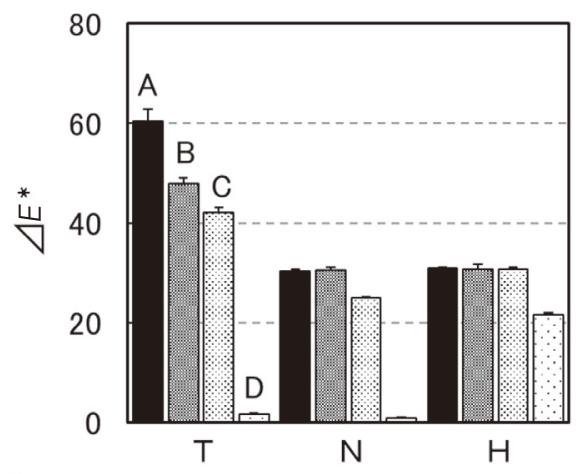

(b)

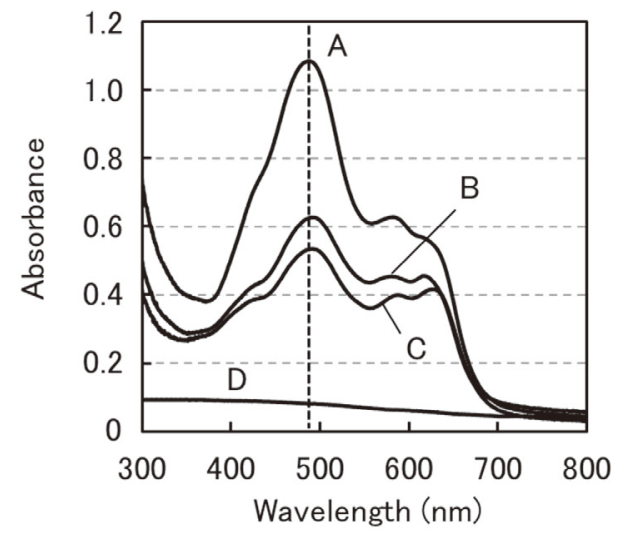

Fig.-2 Color difference and absorption spectra of the keratin films and hair after treatment with semipermanent hair colors.

The color of the samples dyed with the commercial semi-permanent hair colors shown in Fig.-1 were measured by a colorimeter and expressed as $\Delta E^{*}$ (a). Absorbance of the dyed translucent keratin film was measured by a spectrophotometer $(b)$.

ンフィルム/分光光度計の組み合わせで分析できることが 明らかとなった。

\section{3. 染色回数と染色時間が着色へ与える影響}

トリートメントタイプの染毛料は永久染毛剂と比べて染 着性が低く色落ちしやすいために短期間に繰り返し染色す ることが推奨されている。このため, 製品 $\mathrm{B}$ と C と透明 型フィルムを用いて染色回数と染色時間が着色に与える影 響を調べた。両製品とも染色回数と染色時間に比例して着 色は増大することが視認でき，それらのスペクトルのパ ターンから色合いは保たれた状態で染着度が増大すること が確認できた（Fig.-3(a)，(b)）。次に，染色回数と染色時 間の変化を $490 \mathrm{~nm}$ の波長で数值化したところ, 吸光度は これらのパラメータに対して直線的に比例して増大した 
(a)

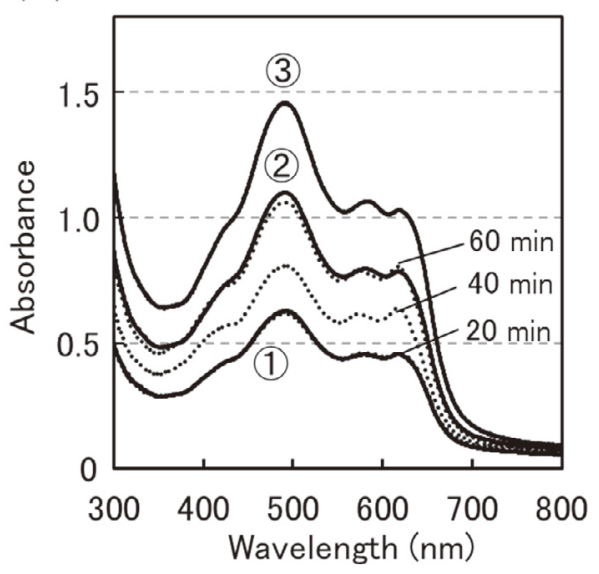

(b)

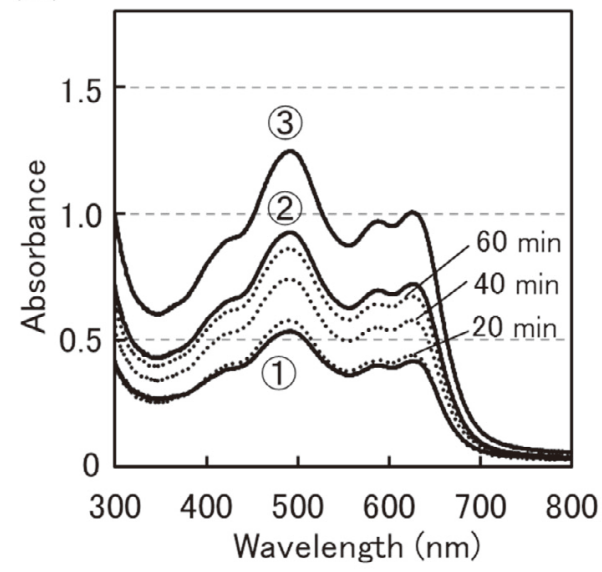

(c)

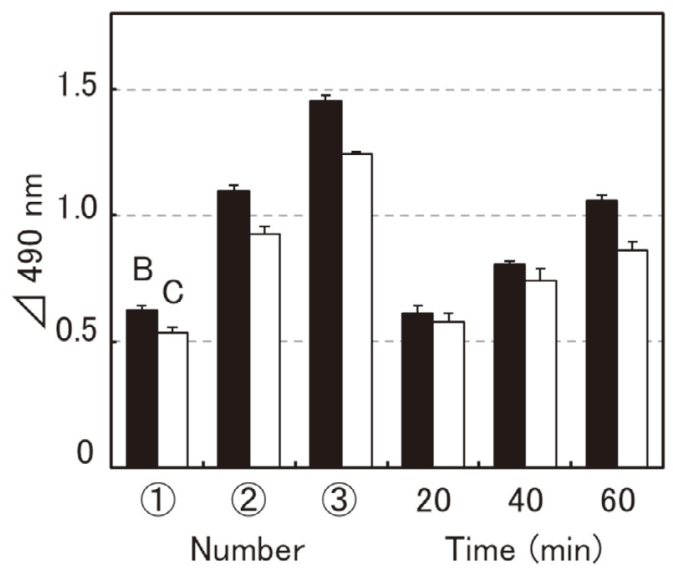

Fig.-3 Effects of dyeing number (solid line ; 20 min $\times$ 3 times) and incubation time (dotted line ; 20 , 40 , and $60 \mathrm{~min}$ ) on the dyeing of the translucent keratin film.

Absorption spectra of the translucent keratin film dyedat $37^{\circ} \mathrm{C}$ with the Product B (a) and Product C (b). Absorbance change at $490 \mathrm{~nm}(\Delta 490$ $\mathrm{nm})$ vs. dyeing number and incubation time $(\mathrm{c})$.
(Fig.-3 (c))。染色回数と染色時間の関係を比較したとこ ろ, 20 分間を 2 回繰り返したフィルムは 60 分間染色処理 したフィルムとほほ同じ吸光度を示した。このため, 染色 時間の延長は濃く染色するために有効ではあるが，染色回 数を増やしたほうがさらに効果的であることが示された。 また，透明型ケラチンフィルムは繰り返しの染色処理に耐 えられ，着色濃度が変化する性質を保持していることも示 された。

\section{4. 二重染色と着色}

施術したへアカラーが期待していた色調や染色濃度に染 まらないなど気に入らない場合，異なるグレードや他社製 品への変更を消費者は選択する。こうしたケースにおいて は，根元付近の生え際では問題が少ないが，すでに染色さ れている毛髪部位においては二重染色となるために，期待 していない色合いとなることが想定できる。

そこで, Fig.-3 に示した製品 $\mathrm{B}$ と C による 2 回染色 (BB, $\mathrm{CC} ） に$ 加えて， B $\rightarrow \mathrm{C}$ と $\mathrm{C} \rightarrow \mathrm{B}$ の順番による 2 重染色を 行った。 $\mathrm{B} \rightarrow \mathrm{C}$ と $\mathrm{C} \rightarrow \mathrm{B}$ の吸光度は $\mathrm{BB}$ と $\mathrm{CC}$ の間の值 を示し、そのスペクトルパターンは $\mathrm{B}, \mathrm{C}$ の 1 回染色での 值を足した計算値（点線）と類似していた（Fig. $-4(a)) 。$ 吸収パターンが異なる 550〜 650 nm を詳細に調べると, BBでは $576 \mathrm{~nm}$ と $616 \mathrm{~nm}, \mathrm{CC}$ では $588 \mathrm{~nm}$ と $628 \mathrm{~nm}$ に低 いピークがあるのに対して， B $\rightarrow \mathrm{C}$ と $\mathrm{C} \rightarrow \mathrm{B}$ でのピーク は $587 \mathrm{~nm}$ と $621 \mathrm{~nm}$ になって扮り両者の中間的な值を示 した（Fig. $-4(b)) 。 L * a * b *$ 表色系を採用している分光測色 計を使用して計測した $\mathrm{L}^{*} \mathrm{a}^{*} \mathrm{~b}^{*}$ に打いても $\mathrm{B} \rightarrow \mathrm{C}$ と $\mathrm{C} \rightarrow \mathrm{B}$ 染色フィルムは $\mathrm{BB}$ と $\mathrm{CC}$ 染色フィルムの中間の值であっ た (data not shown)。

これらの結果，毛髪ケラチンをターゲットとした染毛料 を開発する上で透明型ケラチンフィルムは有用な代替毛髮 デバイスになることが示唆された。

\section{5. システイン酸の形成}

髪に優しいとされている半永久染毛料は， 1 剂 $/ 2$ 郕タイ プの永久（酸化）染毛剂の 2 郕で使用されている過酸化水 素などの強力な酸化剂を添加することなく染髪できる特色 がある。毛髪タンパク質に多く含まれているシスチン/シ ステインが過酸化水素により酸化を受けるとシステイン酸 が生成する。この副生成物はシスチンへの再結合ができな いことに加えて表面電荷を大きく変化させることからダ メージ分子として知られている。この検出にはアミノ酸分 析やフーリエ変換型赤外分光光度計（FT-IR）が使われて

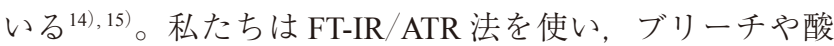
化染毛剂で処理したケラチンフィルムにおいてシステイン 酸が高感度で検出できることを報告してきている2),5), 13)。 そこで, 製品 B と Cで 1 3 回繰り返し染色した透明型ケ 
(a)

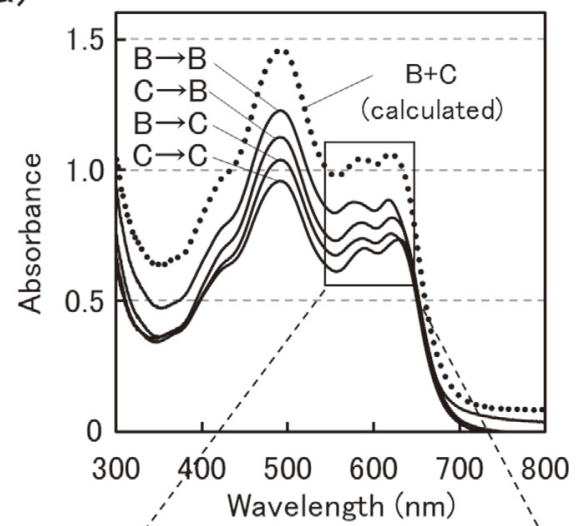

(b)

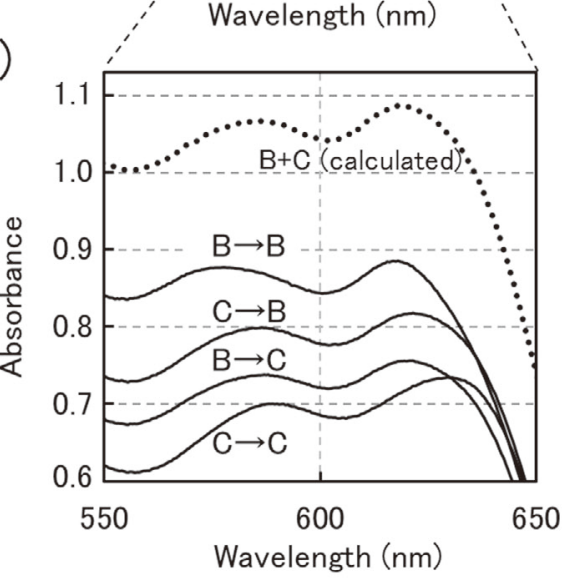

Fig.-4 Effect of double dyeing on the translucent keratin film with the Products B and C.

Absorption spectra at $300-800 \mathrm{~nm}$ (a) and the enlarged illustration at 550-650 nm (b) of the double dyeing of the translucent keratin film.
ラチンフィルムを粉末とし，これらに含まれるシステイン 酸を $3 \%$ 過酸化水素で処理したフィルムをコントロールと して測定した（Fig.-5）。システイン酸に由来する $1041 \mathrm{~cm}^{-1}$ のピークは過酸化水素処理したフィルムに拉いてのみ検出 することができた。つまり, 両製品ともに 3 回までの染色 によりダメージ分子として知られているシステイン酸はほ とんど生成していないことが示された。

\section{6. 水処理が退色に与える影響}

水, 光, シャンプー類処理などがカラー毛髪の退色を引 き起こす要因と考元られている。永久染毛剂染色後の不透 明型と透明型ケラチンフィルムは水道水により色落ちが著 しく生じ，簡便に分析ができることから，染着性だけでな く退色の評価への染色フィルムの活用も提案している2),5)。

製品 $\mathrm{B}$ と C で 1 回染色した透明型ケラチンフィルムを 用いて, 退色性に関して調べた。蒸留水と水道水に $40^{\circ} \mathrm{C}$ で 60 分間浸した後にフィルムのみならず最初の浸水液を 回収して吸収スペクトルを測定した。浸水後のフィルムに (a)

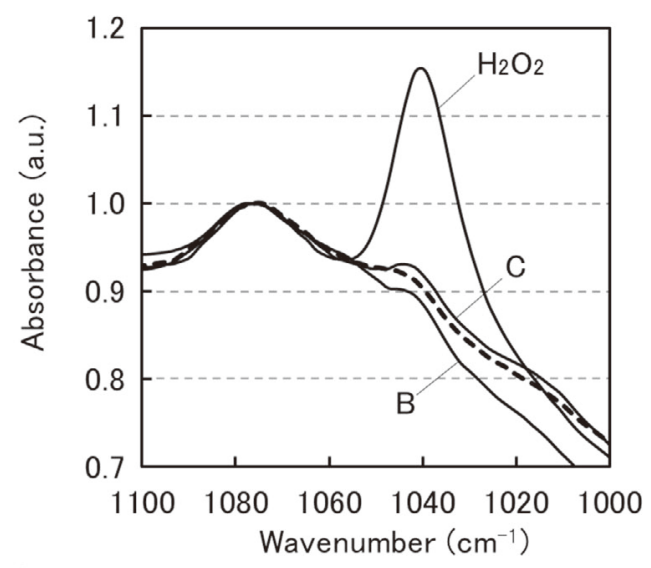

(b)

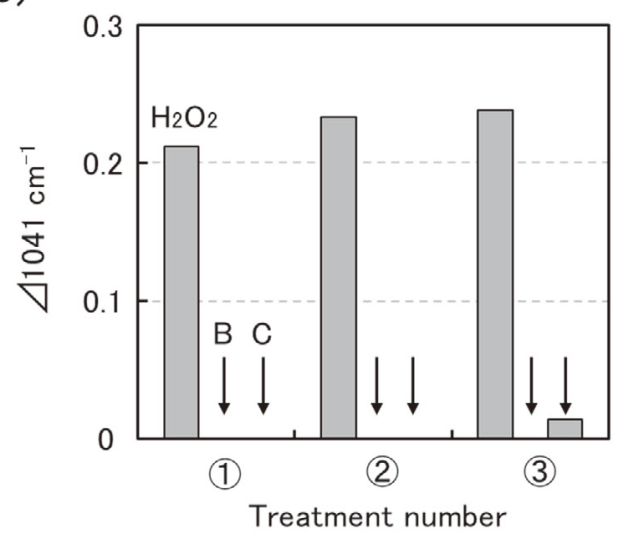

Fig. -5 FT-IR spectra of the translucent keratin film after treatments with Products $\mathrm{B}$ and $\mathrm{C}$, and $\mathrm{H}_{2} \mathrm{O}_{2}$. The keratin films were treated for $20 \mathrm{~min}$ at $37^{\circ} \mathrm{C}$ (up to 3 times) with Products $\mathrm{B}$ and $\mathrm{C}$, and $3 \% \mathrm{H}_{2} \mathrm{O}_{2}$ (a). Spectra after 1 time were normalized as 1 at the peak of $1076 \mathrm{~cm}^{-1}$. Dotted line, untreated film ; solid line, films after being treated for 3 times. Relative amounts of cysteic acid $\left(1041 \mathrm{~cm}^{-1}\right)$ from the treatments $(1-3$ times) (b).

おいては幅広い波長（400～600 nm）での吸光度は低下し ており，この退色性は浸水液に扔いても確認することがで

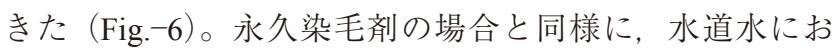
ける退色性は蒸留水と比べ両製品とも高かった。

永久染毛剂で染色したケラチンフィルムに拈いてもその 色落ちは蒸留水よりも水道水で処理したほうが顕著で，金 属イオンがこの原因物質として知られている2),5)。このた め製品 B と C で染色したケラチンフィルムを用いてキ レート剤のEDTA とカルシウムとマグネシウムイオンの 影響を調べた。浸水前後でのフィルムの色差変化を調べた ところ, 両製品とも蒸留水よりも水道水で処理した方が 
(a)

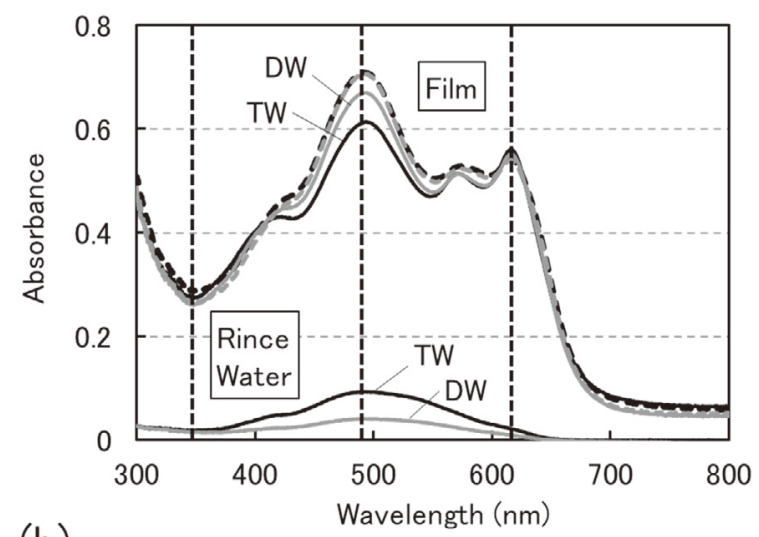

(b)

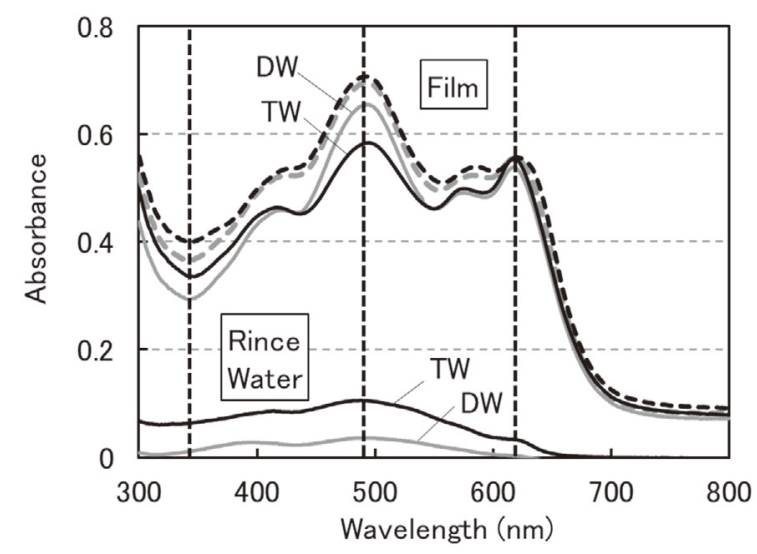

Fig.-6 Effect of water on the fading of the dyed translucent keratin films with Products B and C.

The dyed keratin films with Products B (a) and $\mathrm{C}$ (b) were incubated with distilled water (DW) and tap water $(\mathrm{TW})$ for $60 \mathrm{~min}$ at $40^{\circ} \mathrm{C}$. Dotted line, film before rinse.

$\Delta E^{*}$ 值は有意に減少していることが確認できた（Fig.-7）。 Fig.-6 と同様に，測色計での結果においても製品 C は製品 $\mathrm{B}$ よりも変化量が大きいことから, 製品間の水による退色 性の相違を検出できることが示された。次に，水道水に EDTA を加えた溶液では $\Delta E^{*}$ 值が低下し, 蒸留水に $\mathrm{CaCl}_{2}$ あるいは $\mathrm{MgCl}_{2}$ を加えた溶液では $\Delta E^{*}$ 值は高くなった。 $\mathrm{Ca}\left(\mathrm{CH}_{3} \mathrm{COO}\right)_{2}$ と $\mathrm{Mg}\left(\mathrm{CH}_{3} \mathrm{COO}\right)_{2}$ を添加した場合も退色の 増大がみられることから塩素イオンの影響はみられなかっ

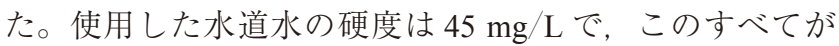
カルシウムイオンによるとして計算すると約 $0.4 \mathrm{mmol} / \mathrm{L}$ の計算値となるため, $0.5 \mathrm{mmol} / \mathrm{L} \mathrm{CaCl}_{2}$ による退色は妥当 と思われた。これらの結果, カルシウムあるいはマグネシ ウムイオンが水に依存した退色に密接に関与していること が明らかになった。

ケラチンフィルムは毛髪内部に存在するケラチンフィラ

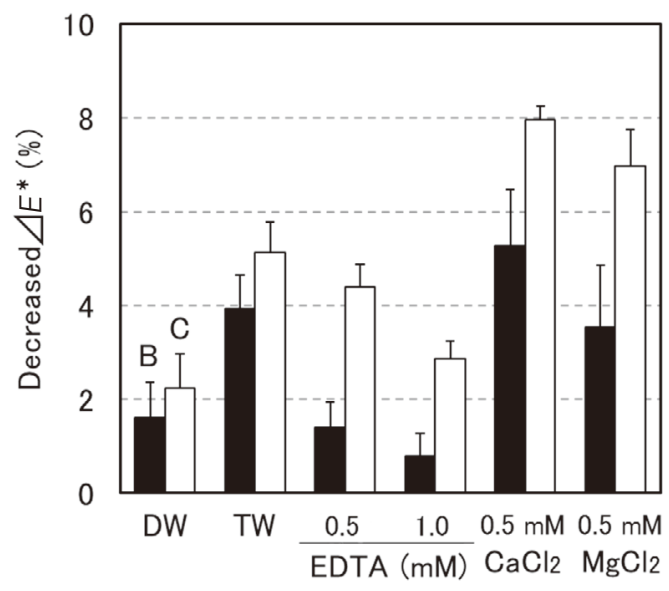

Fig.-7 Effects of EDTA, $\mathrm{CaCl}_{2}$, and $\mathrm{MgCl}_{2}$ on $\Delta E^{*}$ value of the dyed translucent keratin films with Products B and C.

The dyed keratin films with Product B and Product $\mathrm{C}$ were incubated with tap water containing EDTA and distilled water containing $\mathrm{CaCl}_{2}$ or $\mathrm{MgCl}_{2}$ for $60 \mathrm{~min}$ at $40^{\circ} \mathrm{C}$. Decreased $\Delta E^{*}(\%)$ : $\left[\Delta E^{*}\right.$ (before fading $)-\Delta E^{*}$ (after fading $\left.)\right] / \Delta E^{*}$ (before fading) $\times 100$.

メントの階層構造, 細胞膜複合体 $(\mathrm{CMC})$ やキューティ クルをもたない。退色に扔いては, 結合・吸着後に解離し た染料あるいは色素が $\mathrm{CMC}$ やキューティクル層に妨げら れることなく外液に漏れることが考えられる。最近，私た ちはケラチンフィルムがシャンプー類の処理にも耐えら れ，その動的な摩擦が变化することを見つけて報告してい

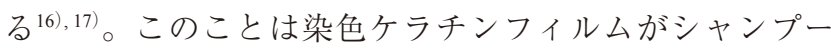
類による退色の分析にも利用できることを示唆しており，

この面からの退色研究を進めている。

\section{7. 光照射が退色に与える影響}

不透明型ケラチンフィルムは光照射に耐えられ，カルボ ニル化タンパク質の形成の分析に利用されている ${ }^{18), 19) 。 ~}$ また，永久染毛剂で染色した透明型フィルムは太陽光照射 システムにより，照射時間に依存した退色をすることを報 告している5)。水による退色実験と同様に，製品 $\mathrm{B}$ と Cで 染色したフィルムの太陽光照射システム（キセノン光源； 300～2500 nm）による退色性を調べた。この結果，両製品 で染色したフィルムの色差には光照射時間に依存した連続 的な低下が観察された（Fig.-8）。相対的な色差の減少率 は製品 $\mathrm{B}$ よりも製品 $\mathrm{C}$ において若干高いことが認められ たが，水や金属イオンによる退色と比べてその製品差はわ ずかであった。同時に測定した吸光度スペクトルからも， 照射時間に依存した同様な退色を確認している。

直径 50〜100 $\mu \mathrm{m}$ のファイバー構造で不揃いな毛髪試料 


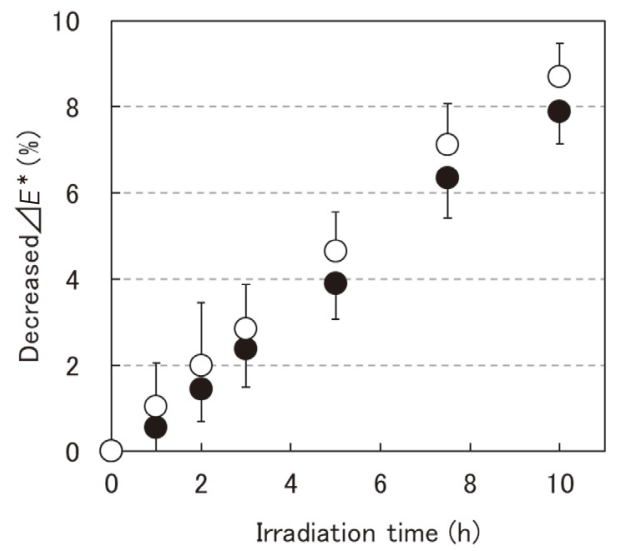

Fig.-8 Effect of light irradiation on $\Delta E^{*}$ value of the dyed translucent keratin films with Products B and $\mathrm{C}$.

The keratin films dyed with Product B $(\mathbf{O})$ and Product C $(\bigcirc)$ were exposed to a solar simulator light for $0^{-} 10 \mathrm{~h}$.

と比べ, 二次元状態で均質性が高いケラチンフィルムはむ らのない均一な光照射が容易にできるばかりか，照射時間 に対して高い相関性をもつ退色の分析ができることが明ら かとなった。このため定量的な退色を評価することが可能 となり，その利便性の高さからも，ケラチンフィルムを光 による退色性が少ない製品開発への利用が期待できる。

\section{4. 結論}

透明型ケラチンフィルムの半永久染毛料による着色と退 色は永久染毛剂の場合と基本的には類似した性質を示し た。染着性に関しては 4 製品中 3 製品において毛髪打よび 不透明型ケラチンフィルム以上の着色がみられた。永久染 毛剂染色後のスペクトルにおいては 450〜550 nm に大きな ピークを示すのみであるのに対して ${ }^{5)}$ ，半永久染毛料の場 合は $490 \mathrm{~nm}$ 付近の大きなピークに加えて， $580 \sim 630 \mathrm{~nm}$ にも小さなピークが確認できた。これは使用した製品に含 まれている染料や色素の種類数が多いことによるものと推 定された。同一製品では染色回数に比例して染色濃度が高 くなることや，異なる製品による二重染色では個々の製品 の中間的なスペクトルがみられることから，毛髪で期待さ れる応答がフィルムに打いても生じて㧍り，その着色性は 簡便に分析できることが明らかとなった。ケラチンフィル 厶は酸性アミノ酸が約 18\%, 塩基性アミノ酸が約 9\%含ま れ，毛髪ケラチンに近いアミノ酸組成から構成されてい る3)。このため，イオン的な相互作用による結合・吸着が 染着性に重要であることが考えられる。製品を使用した実 験系では多くの薬品が含まれており複雑であるため, 最小
限の染料と色素を使用したシンプルな実験系での分析がメ カニズムの解明に必要である。

便利な永久染毛剂で多用されているパラフェニレンジア ミンは高い抗原性を示すことから，この使用がアレルギー やかぶれを惹起することが問題となってきている20,21)。 また，永久染毛剂（二剤タイプ）で使われている過酸化水 素はシステイン酸を生成するが，半永久染毛料による処理 ではこのダメージ分子の生成はほとんどみられなかった。 高齢化が進むわが国において，50 代からへアカラーをは じめると 20 年以上は続けることが想定できる。長期間使 用する顧客にとっては低アレルゲン性でダメージレスな半 永久染毛料に対する染着性と退色性への改善要望は，ます ます高まるものと思われる。このニーズを満たす原料の探 索, 染毛料の開発, 色落ち防止シャンプー類, 洗髪水と光 退色の評価に透明型ケラチンフィルムを活用することは研 究生産性向上につながるものと考えられる。

\section{引用文献}

1）鈴木高広，フレグランスジャーナル，43（6), 53-62 (2015)

2）藤井敏弘，フレグランスジャーナル，42（3), 48-53 (2014)

3）藤井敏弘，コスメティックステージ，8（2)，20-26 (2013)

4）藤井敏弘, 伊藤弓子, 繊維学会誌, 71, 207-212（2015）

5）藤井敏弘, 田村朋宏, 林 香, 伊藤弓子, 繊維学会 誌, 72, 96-103 (2016)

6) H. Søsted, U. Hesse, T. Menne, K. E. Andersen, J. D. Johansen, Br. J. Dermatol., 153, 132-135 (2005)

7）安永秀計, 松原孝典, フレグランスジャーナル, 42 (3), 23 (2014)

8) L. Langbein, M. A. Rogers, H. Winter, S. Praetzel, J. Schweizer, J. Biol. Chem., 276, 35123-35132 (2001)

9) A. Nakamura, M. Arimoto, K. Takeuch, T. Fujii, Biol. Pharm. Bull., 25, 569-572 (2002)

10) T. Fujii, D. Ogiwara, M. Arimoto, Biol. Pharm. Bull., 27, 89-93 (2004)

11) M. M. Bradford, Anal. Biochem., 72, 248-254 (1976)

12) T. Fujii, Y. Takashima, S. Takayama, Y. Ito, T. Kawasoe, J. Jpn. Cosmet. Sci. Soc., 37, 165-170 (2013)

13) T. Fujii, Y. Ito, T. Watanabe, T. Kawasoe, J. Cosmet. Sci., $63,15-25(2012)$

14) V. Signori, D. M. Lewis, Int. J. Cosmet. Sci., 19, 1-13 (1997)

15) R. Kon, A. Nakamura, N. Hirabayashi, K. Takeuchi, J. Cosmet. Sci., 49, 13-22 (1998)

16）藤井敏弘，比嘉善一，伊藤弓子，川副智行，粧技誌， 49, 328-333 (2015)

17) T. Fujii, Y. Higa, T. Okazima, Y. Ito, M. Koseki, J. Fiber 
Sci. Technol., 72, 166-172 (2016)

18) T. Kawasoe, T. Watanabe, T. Fujii, J. Jpn. Cosmet. Sci. Soc., 34, 287-291 (2010)

19) T. Kawasoe, T. Watanabe, T. Fujii, J. Soc. Cosmet. Chem. Jpn., 45, 100-107 (2011)
20) K. Nishioka, M. Murata, T. Ishikawa, Jpn. J. Dermatol., 106, 1397-1401 (1996)

21) H. Søsted, T. Agner, K. E. Andersen, T. Menne, Contact Derm., 47, 299-303 (2002) 